\title{
STUDY ON ENVIRONMENTAL QUALITY AND HAZARD IDENTIFICATION OF UNDERGROUND COAL GASIFICATION PROJECT: A LITERATURE STUDY AND FIELD SURVEY
}

\author{
KAJIAN KUALITAS DAN IDENTIFIKASI BAHAYA LINGKUNGAN \\ PENGEMBANGAN GASIFIKASI BATUBARA BAWAH TANAH: \\ TINJAUAN LITERATUR DAN SURVEI DI LAPANGAN
}

\author{
RETNO DAMAYANTI \\ R\&D Centre for Mineral and Coal Technology \\ Jalan Jenderal Sudirman 623 Bandung 40211 \\ Ph. (+6222) 6030483, Fax. (+6222) 6003373 \\ e-mail: retno.damayanti@esdm.go.id; retnograndis@gmail.com
}

\begin{abstract}
Underground coal gasification (UCG) is a procedure to extract synthesis gas (syngas) from the in situ underground coal seams that could not be extracted by conventional mining methods. This is a clean technology as an alternative method for direct in situ coal conversion. This process involves some heavy equipment and complex operation. Hazards identification and risk assessment in the UCG Project involve identifying the environmental hazards that cover physical, chemical and biological environments to predict the process sequences, its frequency as well as consequences that lead to those hazards. The assignment of risk level is also conducted to design corrective action in minimizing the risk or eliminating the hazards. The environmental condition of the project plan is generally good with the fulfillment of the established environmental quality standards.
\end{abstract}

Keywords: underground coal gasification, risk, hazard identification, risk assessment

\begin{abstract}
ABSTRAK
Gasifikasi batubara bawah tanah merupakan cara mengekstraksi gas sintesis secara insitu dari lapisan batubara bawah tanah yang tidak dapat dieksploitasi secara konvensional. Teknologi ini merupakan teknologi bersih yang merupakan metode alternatif konversi langsung batubara. Prosesnya menggunakan peralatan berat dan pengoperasiannya kompleks. Identifikasi bahaya dan pengelolaan risiko pada proyek UCG dilakukan untuk memperkirakan keamanan rangkaian prosesnya yang mencakup kondisi lingkungan fisik, kimia dan biologi lingkungan sekitarnya serta frekuensi keberlangsungan dan konsekuensi terjadinya bahaya. Kondisi dasar lingkungan tersebut selanjutnya dipakai acuan dalam pengelolaan lingkungan di sekitar rencana proyek. Tingkat risiko bahaya yang akan terjadi pada dasarnya akan dapat diprediksi dari awal berikut rencana aksi koreksinya. Secara umum kondisi lingkungan daerah rencana proyek masih baik dengan terpenuhinya baku mutu lingkungan yang ditetapkan.
\end{abstract}

Kata kunci: gasifikasi bawah tanah, risiko, identifikasi bahaya, pengelolaan risiko

\section{INTRODUCTION}

The pilot project of Indonesia UCG research is one of the pioneer projects in the development of new energy research which utilizes the unmineable coal resources conducted by the Research and Development Centre for Mineral and Coal Technology (RDCMCT). The project had identified the hazards, assessed the associated risks and brought the risks into a tolerable level so it could be sustained in the 
next project. All mining activities that have a hazardous operation generally possess considerable risks to the people and environment. Unsafe conditions and practices in activities lead to a number of accidents and cause loss and injury to human lives, damage the environment and property, interrupt production, etc.

For being a successful research, the development project should meet either the final product requirement or highest safety standards in all concerned aspects including the health and environmental condition. Due to the existing hazard and complexity of mining activities, associated system, procedure, and methods of the process, it is difficult to say that the UCG research project is naturally safe. There will be always the potential for serious hazards. It is impossible to guarantee that the project is totally safe. Hazard identification and risk analysis involve identification of undesirable events that lead to a hazard, the analysis of its mechanism by predicting the undesirable event which might occur and estimating extent, magnitude, and the likelihood of harmful effects that usually goes on.

The objective of the study is to identify:

- the baseline condition of the environment nearby the UCG pilot project;

- the hazard and risk identification that lead to the development of the project.

Though there are many techniques or methods, the preliminary pilot project paper presents a single methodology to identify and analyze the hazards.

\section{Risk Assessment of UCG Technique}

Risk assessment is the process used to determine whether people may expose to an injury, illness or disease in the workplace arising during the hazard identification process. The risk occurs when a person is exposed to a hazardous situation that will lead to an injury or a health issue. It is a measure of the probability and potential severity of harm or loss. Risk assessment forms a crucial early phase in the disaster management planning cycle and is essential in determining what disaster mitigation measures should be taken to reduce future losses. Any attempt to reduce the impact of disaster requires an analysis that indicates what threats exist, who or what they may affect, why and what makes a person or a community more vulnerable than another kind of available technology that determines the steps to reduce the UCG risk. The risk assessment is carried out in a series of related activities which builds up a picture of the hazards and vulnerabilities which explain disaster events.

In the case of the UCG pilot project, hazards identification should be traced from drilling activities to its operation plan. Even in Indonesia, the UCG is still in the research pilot project; at least the hazard should be predicted from the beginning.

\section{UCG Technologies}

Underground coal gasification (UCG) is a procedure to extract the synthesis gas (syngas) from in situ underground coal seams that could not be extracted by conventional mining methods (Verma et al., 2014)The technique is also known as a clean energy technology and serves as an alternative method for direct in situ coal conversion method. The UCG process is the most environmentally friendly use of coalrelated to its recovery, chemical feedstock value, environmental impact, health and safety benefit, process efficiency and economic potential (Imran et al., 2014).

Many countries had tested the UCG technology in many different experimental tests, such as the USA (1975-1996), Soviet Union (1969-now), China and Australia (2000). The multiple commercial projects are still developed in various stages in the US, Canada, South Africa, India, Australia, New Zealand, and China. These are mostly to produce power, liquid fuels, and syngas (Table 1). The UCG technologies seem economically promising compared to the surface gasification process because there is no purchase of gasifier. From the operation point of view, these categorize as low expense technologies due to the lack of mining, transporting and ash management facilities.

Most of the projects are still in the research and development categories. Some of them show successful facts and the others have environmental problems. These technologies may generally affect the natural environment, however, the activities still try to deal with the arising environmental problems. The 
technology is site-specific and its commercialization is being hindered due to the lack of complete information for a specific site of operation (Khan et al., 2015).

Table 1. Summary of World UCG Project

\begin{tabular}{|c|c|c|c|c|}
\hline No. & Country & Company/Project & Date of Operation & $\begin{array}{c}\text { Findings, Comments, } \\
\text { Concern }\end{array}$ \\
\hline 1 & USSR & Linc Energy & 1930s, 1955 - 1996 & $\begin{array}{l}\text { Research \& development } \\
5 \text { UCG plants produced gas } \\
\text { for boilers. Production } \\
\text { peaked in the } 1970 \text { s } \\
\text { Very large scale - gasified } \\
\text { over } 300 \text { times the total } \\
\text { amount of coal in all the } \\
\text { U.S. \& Austrian projects }\end{array}$ \\
\hline 2 & USA & $\begin{array}{l}\text { US Bureau of Mines } \\
\text { Gorgas, Alabama }\end{array}$ & $1940 s-1950 s$ & $\begin{array}{l}\text { Initial UCG tests in } \\
\text { Alabama. }\end{array}$ \\
\hline 3 & USA & Hoe Creek & 1970s & $\begin{array}{l}\text { Tests resulted in significant } \\
\text { groundwater contamination. }\end{array}$ \\
\hline 4 & USA & Rocky Mountain I & $1972-1989$ & $\begin{array}{l}30 \text { experiments conducted } \\
\text { in Wyoming, Texas, and } \\
\text { Washington }\end{array}$ \\
\hline 5 & France & La Haute Deule & $1980-1981,1983$ & $\begin{array}{l}\text { Failed tests - poor hydraulic } \\
\text { connection }\end{array}$ \\
\hline 6 & USA & Rocky Mountain I & $1980 s$ & $\begin{array}{l}\text { Most successful UCG } \\
\text { venture in U.S. Plans for a } \\
\text { commercial scale operation } \\
\text { were cancelled due to lack } \\
\text { of support }\end{array}$ \\
\hline 7 & China & $\begin{array}{l}\text { Sino Coking Coal and } \\
\text { Coke Chemical } \\
\text { Industries, Inc. } \\
\end{array}$ & $1980 s$ & $\begin{array}{l}\text { Trials carried out using } \\
\text { galleries of abandoned coal } \\
\text { mines. }\end{array}$ \\
\hline 8 & Belgium - Germany & Belgian/German JV & 1982 & Unsuccessful tests \\
\hline 9 & Spain & $\begin{array}{l}\text { Spanish, UK, Belgian JV } \\
\text { supported by EU }\end{array}$ & $1993--1998$ & $\begin{array}{l}\text { Tested depths greater than } \\
500 \mathrm{~m} \text { project ended when } \\
\text { reactor failed } \\
\text { Three attempts to create } \\
\text { UCG process. Malfunction } \\
\text { during the third test led to a } \\
\text { methane explosion. }\end{array}$ \\
\hline 10 & China & - & 1991-present & $\begin{array}{l}\text { China currently has the } \\
\text { largest UCG program with16 } \\
\text { UCG pilot projects carried } \\
\text { out. }\end{array}$ \\
\hline
\end{tabular}

Solid Energy New

Zealand Ltd With US

11 New Zealand

technical assistance

Since 2005, with Ergo

Exergy Technologies Inc

12 Australia

Linc, Chinchilla

1999-2002
1994 13-day trial. Full gasification was not achieved.

Stands out for its successful siting, operation, and environmental management efforts but not for its commercial success.

Also demonstrated feasibility of control for UCG process, shut-down, and startup, Ergo Exergy Technology, Inc.

Test successful, plans to build $2100 \mathrm{MW}$ power plant, Ergo Exergy technology Inc. 


\begin{tabular}{|c|c|c|c|c|}
\hline No. & Country & Company/Project & Date of Operation & $\begin{array}{l}\text { Findings, Comments, } \\
\text { Concern }\end{array}$ \\
\hline 15 & Australia & $\begin{array}{l}\text { Carbon Energy, Blood- } \\
\text { wood Creek }\end{array}$ & 2008-present & - \\
\hline 16 & Australia & Cougar, Kingaroy & TBD & $\begin{array}{l}\text { Ergo Exergy Technology } \\
\text { Inc. }\end{array}$ \\
\hline 17 & Canada & Laurus & TBD & $\begin{array}{l}\text { Ergo Exergy Technology } \\
\text { Inc. }\end{array}$ \\
\hline 18 & China & ENN, Tongliao & TBD & - \\
\hline 19 & New Zealand & Solid Energy, Huntley & TBD & $\begin{array}{l}\text { Ergo Exergy Technology } \\
\text { Inc. }\end{array}$ \\
\hline 20 & Canada & Swan Hills LLC & TBD & $\begin{array}{l}\text { Completed first } \\
\text { demonstration phase in July } \\
2009 \text {. } \\
\text { Gasification occurs at } 1,400 \\
\mathrm{~m} \text {, has } \$ 285 \text { million funding } \\
\text { from the carbon capture and } \\
\text { storage fund. }\end{array}$ \\
\hline 21 & South Africa & Sasol & TBD & - \\
\hline 22 & United States & GasTech & TBD & $\begin{array}{l}\text { Ergo Exergy Technology } \\
\text { Inc. }\end{array}$ \\
\hline 23 & United States & Laurus & TBD & $\begin{array}{l}\text { Ergo Exergy Technology } \\
\text { Inc. }\end{array}$ \\
\hline
\end{tabular}

Note: TBD: to be determined

Modified from: Moorhouse, Huot and McCulloch (2010); Burton, Friedmann and Upadhye (2007)

The major concern of UCG potential hazards that should optimally be managed are surface subsidence and groundwater contamination. Other environmental concerns related to the UCG that must be taken into account are carbon dioxide emission and carbon captured storage (CCS), and other air emissions.

The general process of surface gasification differs from the UCG which proceed directly in situ for gasifying the uneconomically and unmineable deep coal seams. The UCG site criteria for choosing the suitable location that must be considered are (Bowen and Irwin, 2008; Mohanty, 2017):

- geology condition that plays a decisive role as a key to safeguard environment throughout the UCG life cycle and is an imperative key in the every UCG project phase;

- coal bed that geologically occurs in the isolated deep beds and has low porosity and less deformation of the impermeable over/underlying strata. This will acts as a seal between the coal seam and the surrounding aquifers so it will be suitable for the UCG processes. The impermeable over/underlying strata will limit the degree of subsidence that mostly occurs in the UCG;
- the aquifer that locates in a deep place and consists of saline, non-drinking water and stratigraphic seals characteristics,

- structural integrity and no possibility of having a hole in the cavity roof.

Principally, combustion ensues at 900 to $1.200{ }^{\circ} \mathrm{C}$ and sometimes $1.500{ }^{\circ} \mathrm{C}$. It produces a synthesis gas called syngas. The reaction process is similar to the surface gasification. The in-situ coal gasification technique generally uses two vertically drilled wells which act as injection and production wells.

The difficulties generally occur during linking the two wells due to the low permeability of the coal seams. There are some techniques to link the wells as follows :

- hydraulic fracking. This technology is common in the oil and gas industry, so is the reverse or forward combustion linking (Shafirovich and Varma, 2009). This technique injected high-pressure water or air, proppants, radioactive tracers, and chemical additives to make a fracture within the coal formation along with other new cracks formation and pathways by which the gases will be extracted. The toxic fracking fluid is predicted as the source of surface or groundwater contaminant which is much irrecoverable during the process. The usage of 
chemical additives is predicted as a cause of fracked well for a number of times;

- reverse combustion. This method links the wells including injection the oxidant into one well and igniting the coal into the other well, so that combustion propagates towards the source of oxidant (Blinderman, Saulov and Klimenko, 2008).

- forward combustion. This technology ignites a fire in the injection well and propagates it towards the production well (Blinderman, Saulov and Klimenko, 2008);

- controlled retractable injection point (CRIP). This is a relatively new technique for in situ gasifications. It is suitable for a thin, deep coal seam to replace the vertical injector by the horizontal one. This technique uses a vertical drilling for its production well. The directional drilling technique is chosen to link the injection and production wells. Once the connection is established, the gasification process can be started at the end of the injection well of the coal seam horizontal section. The directional drilling technique is a proven technology in the oil and gas. Other linking method to connect the desired point in the coal bed is electro linking (performed by passing a current through the coal seam for the carbonizing process) and explosive in seam linking (performed by liquid explosive)

\section{General UCG System}

As the conversion process of coal to gas, the UCG is classified as a very difficult and complex process because there are many changes in the parameters as long as the operation and also changes in the space of the reactor due to the variety in its phenomenon. The UCG requires a proper site selection, geometry model of the reactor, composition and injection rate of gasifying agent and environmental monitoring. Ideally, the UCG should predict some important aspects of its process such as syngas composition and heat value, cavity growth, water influx to the reactor, roof collapse and subsidence, and last but not the least, is the contaminant transport of the reactor. The UCG system covers underground coal seams (reserve, composition etc.), wells (injection and production), and installations for air/oxygen tank and gas productions presented in Figure 1 (Krause, 2011).

The UCG technique offers a significant number of potential advantages. Those are:

- eliminating the surface coal mining technology, surface gasification plant, ash disposal or storage, and its leachate problem;

- reducing the overall capital cost and another operation cost like the cost for sulphur and heavy metals removal;

- reducing the health and safety problem associated with conventional coal processing techniques and the socioeconomic impacts as well;

- utilizing the deep coal reserves which recovered uneconomically using conventional technique;

- providing high thermal efficiencies, more economic synthesis gases, and less intensive fuel gas treatment ;

- requiring less stringent feed water quality requirement, permitting consideration and directional drilling technology.

Some technical requirements for UCG operation that must be fulfilled are (Rosso Murillo, 2013; Mocek et al., 2015):

- the top and bottom layers of coal seam must be impermeable layers;

- the coal seam thickness should be more than $5 \mathrm{~m}$;

- the coal seam must be located over 200 $\mathrm{m}$ of depth ;

- the condition is not a complex geological structure;

- coal ash and moisture content are less than $60 \%$;

- the minimum-coal reserve is about 150 million tons to produce $155 \mathrm{mmscfd}$ of energy for 25 years.

The system shows that there must be awareness in assessing the surface water and groundwater resources (include supply and contamination problems), other environmental (soil and air), health and economical aspects. Major concerns are especially about transporting the contaminant into surface and groundwater, escaping of product gases and also the groundwater impact as resources. 


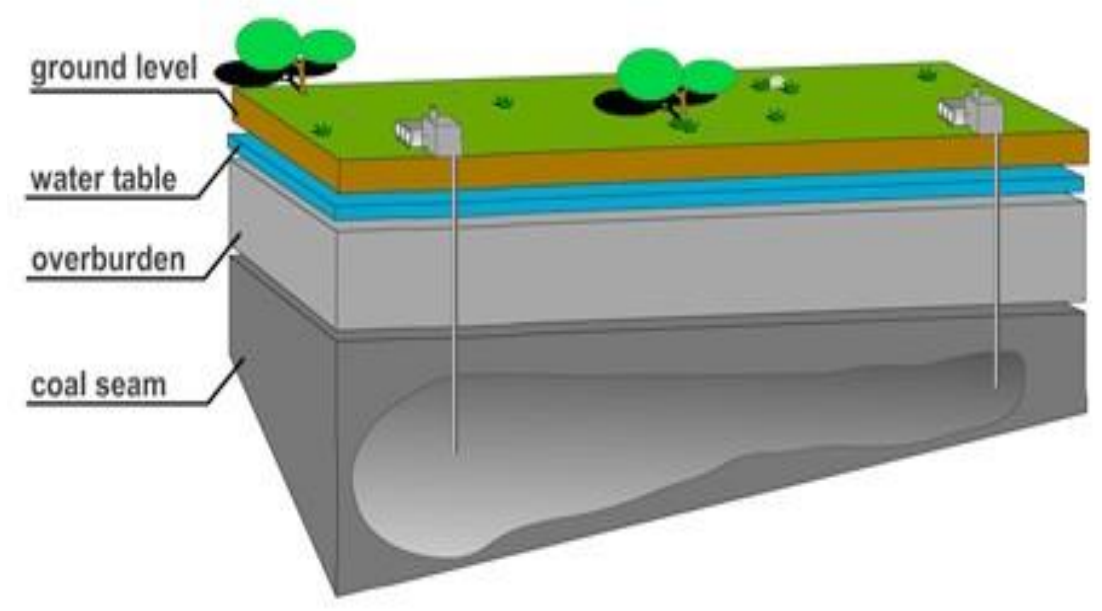

Figure 1. The underground coal gasification system (Krause, 2011)

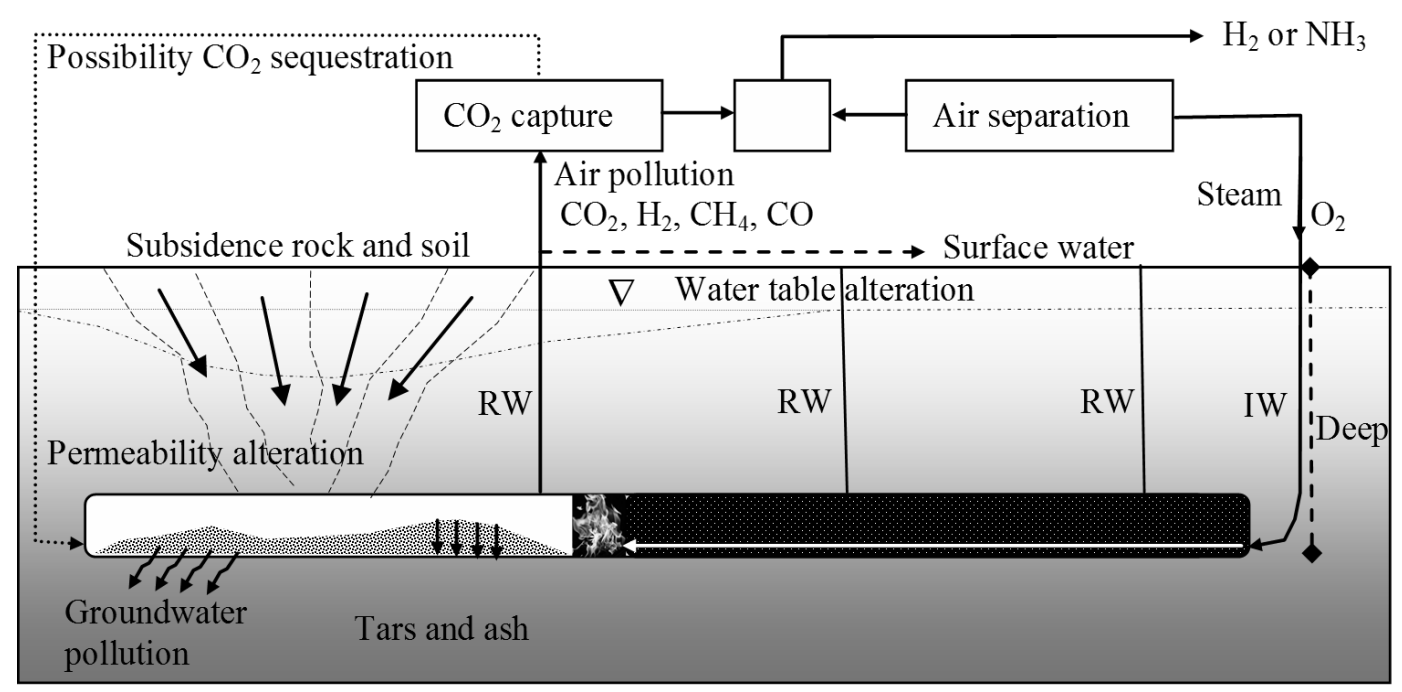

Figure 2. Interaction UCG and its environment (Torres, Atkins and Singh, 2014)

\section{Environmental Risk of UCG}

Environmental contamination problems are complex issues with worldwide implications. Risks, especially to human and ecological health or to the environment as a result of toxic materials introduction, are a great interest to modern society. Therefore, the effective management of the environmental contamination problem has become an important environmental purpose that will remain as a social issue for the future. Basically, the risk assessment methodologies have traditionally been based on the effect of examination to the human health, but right now much more emphasis is placed on all types of environmental damage. Compare to the human health risk assessment, which is a relatively new field, the risk assessment for ecological effects is still in growing and developing the condition. This paper focuses on the environmental risk in the UCG system.

UCG is still experimental to trial coal combustion technology. Small-scale trials of the UCG, over the last 80 years, have invariably resulted in severe water contamination, including its long-term contamination of aquifers and/or explosions (Table 2). The Environmental Risk Assessment (ERA) should consist of evaluating the probability that adverse effects 
on the environment or human health, occur or may occur as a consequence of exposure to physical, chemical or biological materials. Evaluation of environmental risk requires knowledge of adverse effects that might be caused by chemical agents exposure, as well as the intensity and duration necessary to produce adverse effects on the environment, including the population. Risk assessment can act as an important role in almost all activities. It plays as a tool used to organize, structure and compile scientific information and also in order to help for identifying the existing hazardous situations, anticipating the potential problems, establishing priorities and providing a basis for regulatory controls and/or proposing the corrective actions. It can also be used to determine and measure the effectiveness of corrective measures or remedial actions.

Based on the UCG histories, there are some potential environmental risks associated with the in-situ gasification, such as:

- subsidence;

- $\quad$ surface and groundwater quality;

- air quality (production and utilization of product gas);

- hazardous by-products or wastes;

- the processes related to UCG which may have a potentially dominant impact in the environment as described in Figure 3.

Considering processes develop in the life cycle of the UCG plant, the environmental risks that might affect significantly are:

1. groundwater risks that come mostly from leaking of drilling fluid contaminant during the drilling process. Other gaseous, liquid and solid substances leakages produced from the UCG process will also be predicted as a major groundwater risk;

2. surface water risks that are predicted from wastewater and produced during UCG product process and treatment. The same risks come to pass in the soil ground surface and also atmospheric condition surrounding the UCG plant. These can be affected by gaseous leakage;

3. deformation of the geological subsurface is another risk that might be taking place. The condition is influenced by the settling of voids left after coal gasification;

4. risk of personal health loss due to the pollutant emission to the environment.

All of those risks are delivered in Figure 3. To quantify how big those risks are, it should be estimated by combining data from laboratory or field studies. From the field studies point of view, the relationship between stressor and complex ecosystem can be evaluated that might not be described in laboratory modelling. Field studies will delineate the real effects which have been estimated in the laboratory modelling.

Since the data are limited or they are not easy to be expressed quantitatively, the risks from the UCG need such a professional judgment and qualitative evaluation for ranking its categories, such as low, medium and high. From the qualitative judgment, it must be translated into a quantitative one. Risk assessment is known as a continuous process. Figure 4 shows the scheme of qualitative and quantitative assessments in risk analysis.

Table 2. Histories of UCG failure track record (Monk et al., 2016)

\begin{tabular}{cll}
\hline Year & \multicolumn{1}{c}{ Location } & \multicolumn{1}{c}{ Accident } \\
\hline 1987 & $\begin{array}{l}\text { Rocky Mountain, } \\
\text { Wyoming }\end{array}$ & $\begin{array}{l}\text { High levels of benzene and other carcinogenic contaminants were } \\
\text { forced into groundwater }\end{array}$ \\
\hline 1997 & El Tremedal, Spain & $\begin{array}{l}\text { Drill site explosion and a blowout of toxic water, Syngas escaped the } \\
\text { burn cavity to surrounding rock strata }\end{array}$ \\
\hline \multirow{2}{*}{2099} & $\begin{array}{l}\text { Linc Energy, } \\
\text { Chinchilla, } \\
\text { Queensland }\end{array}$ & $\begin{array}{l}\text { Test discontinued, } 300 \mathrm{~km}^{2} \text { of farmland contaminated with toxic gas. } \\
\text { Company then, charged with causing serious environmental harm in } \\
2015\end{array}$ \\
\hline \multirow{2}{*}{2010} & $\begin{array}{l}\text { Eskom, Majuba, } \\
\text { South Africa }\end{array}$ & $\begin{array}{l}\text { Two well failures and high volumes of liquid waste caused disposal } \\
\text { problems. The syngas produced contained toxic and corrosive } \\
\text { hydrogen sulphide }\end{array}$ \\
& $\begin{array}{l}\text { Cougar Energy, } \\
\text { Kingaroy, } \\
\text { Queensland: }\end{array}$ & $\begin{array}{l}\text { The Kingaroy UCG well exploded after only five days of operation and } \\
\text { resulted in carcinogenic benzene and toluene being detected in } \\
\text { groundwater and in the fat of animals grazing in fields at the surface. } \\
\text { The company then prosecuted and fined in } 2013\end{array}$ \\
\hline
\end{tabular}




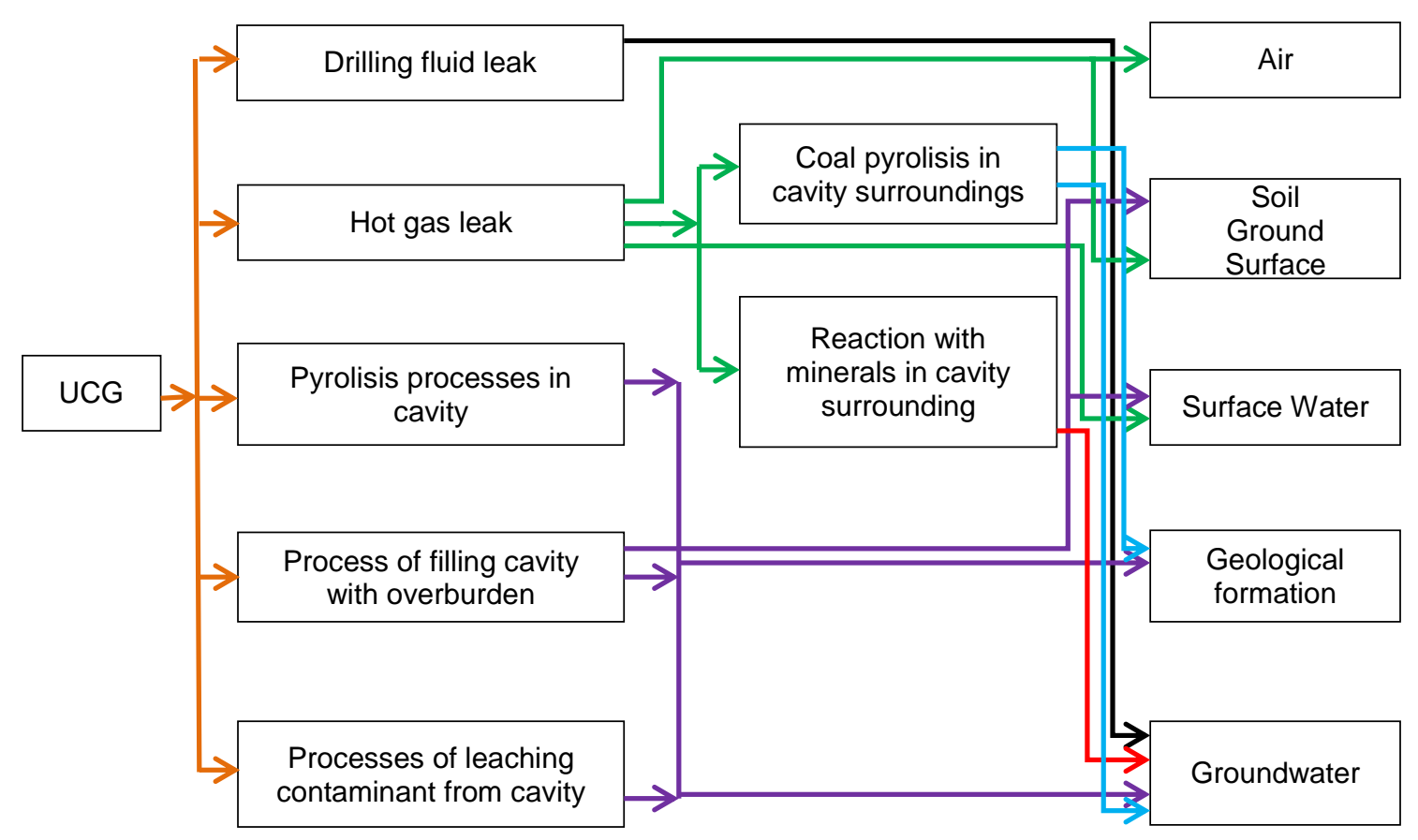

Figure 3. Environmental impact of UCG (Świądrowski and Stańczyk, 2016)

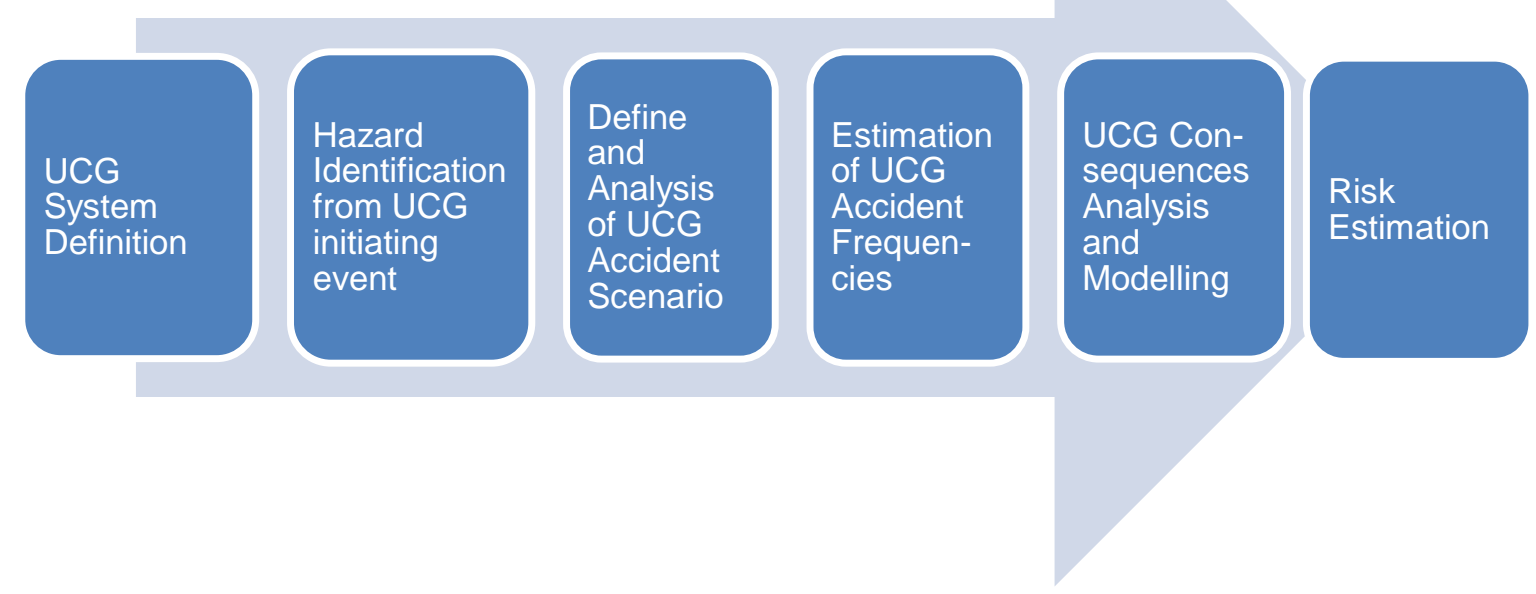

Figure 4. Scheme of UCG global hazard identification and risk estimation (Shrivastava and Patel, 2014)

Based on the above facts, the UCG monitoring program needs implementation strategies for having good achievements. The monitoring should be conducted in some stages such as (Mohanty, 2017):

- planning and assessing phase. Site characterization, either geographically or geologically, is an important stage, which can be used for designing arrays to meet the requirements of regulators and other stakeholders;

- baseline monitoring. The pre-combustion baseline surveys must be carried out reliably to provide the background values and as a basis for mapping;

- operational monitoring. The sampling must be conducted regularly and frequently during the combustion process 
for near real-time monitoring of the injection/production wells. This activity is conducted to look for circulation behind casing, failures within the wellbore and observation ground deformation, groundwater contamination and other operational problems or failures above and under surface location.

- series of monitoring during and after gasification. The monitoring phase in the long-term condition in post-combustion involves active surface and subsurface series. It should be included with the option for evaluation tools around the high-risk zones. The iteration and total duration of monitoring are to be determined by the goals, the site parameters, the budgetary status, and regulatory needs.

Monitoring program must cover the UCG lateral and vertical network of near, middle and far monitoring wells to collect data and samples from the coal seam, overburden, interburden and underburden.

Besides the routine monitoring instrumentation, modern technologies are available for monitoring activities which can be deployed to generate high-density 2D/3D data. The electromagnetic imaging, resistance tomography, seismic and magnetotelluric techniques can be used for detecting the burn front and delineating the cavity growth. The extensometers, shear strips, and piezometers are generally used to monitor surface deformation. New techniques like tilt meter and InSAR are also available for monitoring deformation and subsidence as long as the fiber optic temperature sensors which are applied for monitoring cavity temperature.

The steps of hazard identification and environmental risk assessment are as follows (Shrivastava and Patel, 2014):

Step 1: UCG system description will define the system and its subsystem and also the future operations;

Step 2: UCG hazard identification will define and describe globally the hazard, including its physical characteristics, magnitude and severity, causative factors, and locations or areas affected;

Step 3: UCG risk analysis will analyze theoretically the probability, frequency or likelihood the potential losses associated with a hazard;

Step 4: UCG risk rating will value of hazard or calculate risk class to give the required action which should be taken by forming a table of risk classification screening;

Step 5: UCG risk resolvement will make corrective action recommendation for preventing, reducing or transferring the risks in the short and long-term planning.

A hazard is an object that causes harm condition, e.g. electricity, chemicals, noise, etc. A risk is the high or low chance that any hazard will actually cause somebody harm. Based on risk classification, the UCG global hazard could be identified and classified in some categories.

\section{METHODOLOGY}

This paper is focused on the baseline environmental condition in the prospected UCG location and general risk identification, so that a factor which must be considered is a little bit different with other integrated risk management which normally covers the health assessment. All of the hazards are still in a predicted model because the Indonesian UCG project is still in progress condition. The quantitative methods maybe cannot analyze various data precisely due to the faced facts exist. So, the review is set up mostly in qualitative data, on either the limited primary and secondary data collected during the research project to be held.

The research approach was guided by such information:

- information sources. Most of the information in this report comes from public literature sources, interviews with UCG researchers in the perspective on the science and technology;

- information types. The information in this paper is primarily qualitative, and (a part of it) quantitative one;

General UCG Technology Review. The RDCMCT proposes to use one specific UCG technology, namely reverse combustion method. The focus is the common environmental risks and benefits of operating the UCG facility regardless of this specific approach. 


\section{RESULT AND DISCUSSIONS}

\section{Proposed UCG System Description}

The upstream activities that had been carried out in the UCG pilot project are mostly drilling and laboratory experiment for igniting the coal. The whole Indonesian UCG research activities plans that had been completed were:

1. coal potency identification in detail, especially the reserves which can be processed by UCG technology;

2. coal drilling for reserves confirmation;

3. establishing the pathway/network for underground UCG;

4. coal ignition;

5. oxygen/air and steam injection;

6. synthetic-gas extraction;

7. establishing the environmental condition before UCG trial;

8. UCG trial;

9. establishing the environmental condition after the trial.

The roadmap study shows that the primary project stage was set up till having the flare. The purpose was to prove that Indonesian coal could be processed using UCG technologies. Yet, step no 6 would not be conducted. The project should also wait the final permission for running the operation.

\section{Indonesia UCG Research Project}

To identify the coal potency, the UCG project utilized secondary data from Geological Agency combined with Advanced Resources International. For the coal reserves confirmation, the RDCMCT conducted some boreholes drilling activities. The coal resources in Indonesia distributes in Sumatera, Kalimantan, Sulawesi, Java, and Papua. Its rank varies from lignite to bituminous. Dealing with Indonesian UCG project, South Sumatera was chosen as the project area at PT. Astaka Dodol area mining permit. Its resource is about 1.964 billion tons with the reserve is about 256 million tons. The Indonesia main coal basin is shown in Figure 5.

After evaluating the primary and secondary data, the prospect location was determined in Astaka Dodol area as a research location (Figure 6). Based on the geological survey result, the trial of UCG process will be conducted at the depth of $80 \mathrm{~m}$ below the surface. This is the minimum depth that the UCG process could be run theoretically in a safe condition.

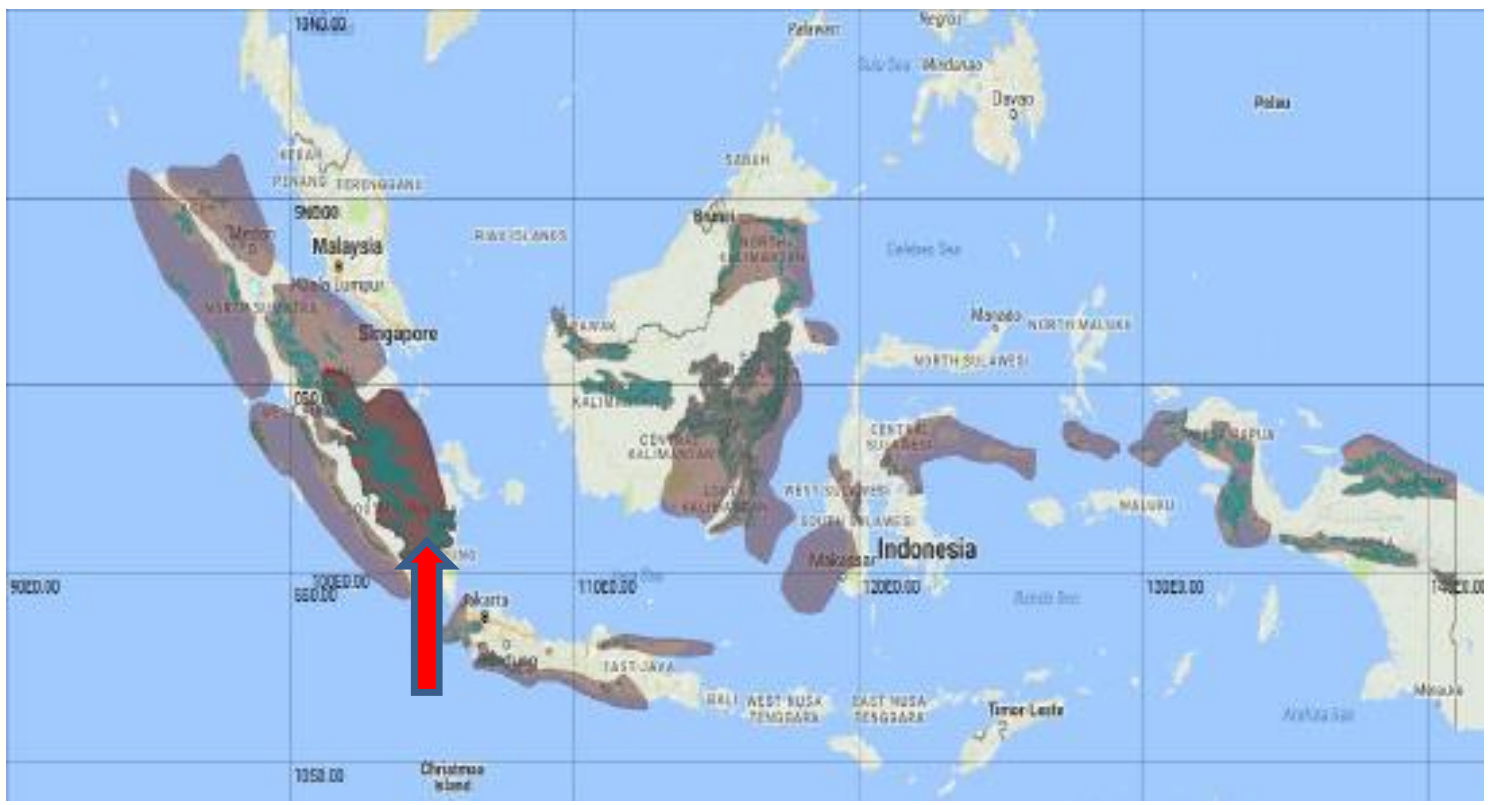

Figure 5. Indonesia Coal Basin Map (modified from Coaltrans Conferences, 2014) 


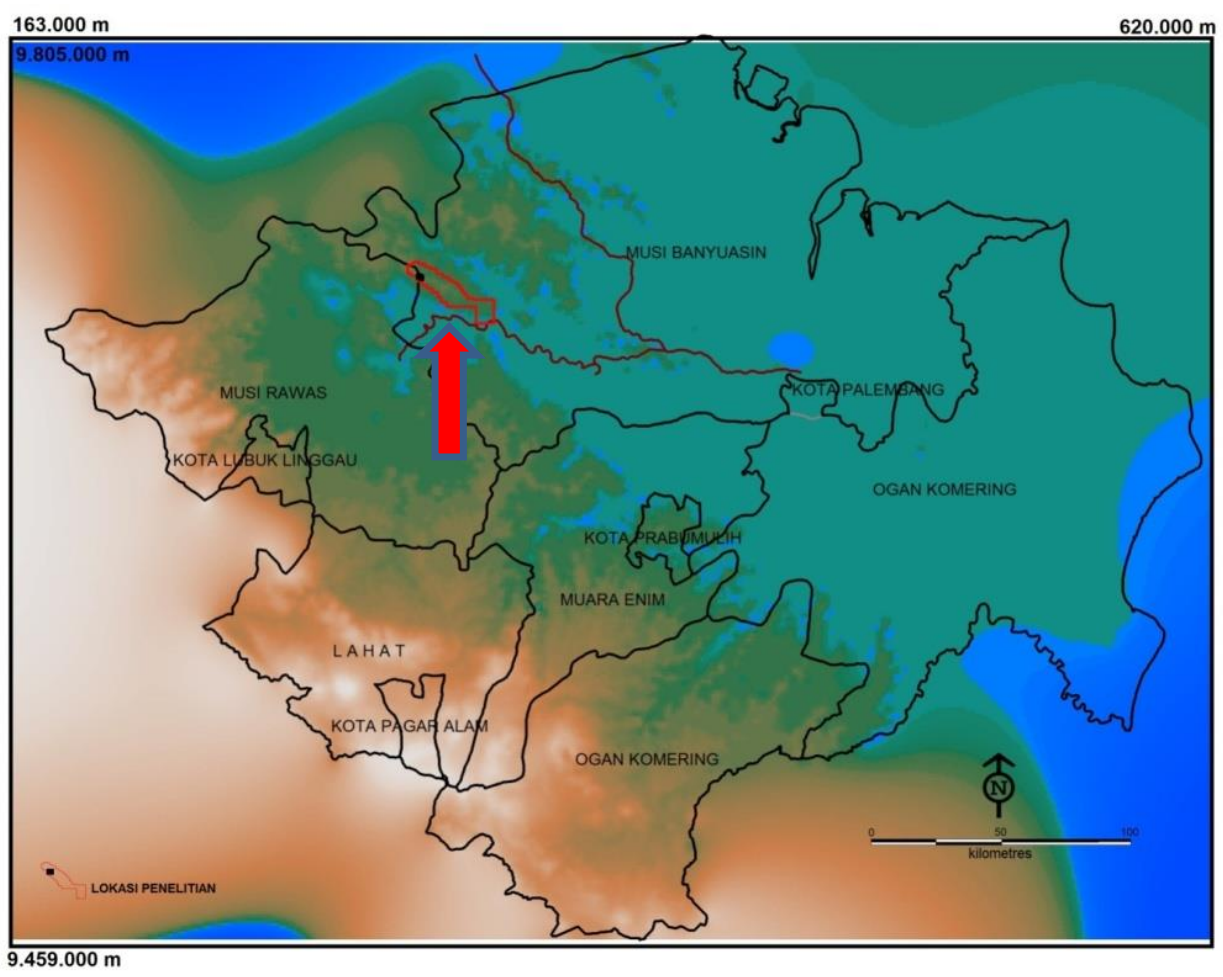

Figure 6. Map of the UCG Research Project in South Sumatera (Purnama et al., 2017)

In the future, Indonesia still depends on its coal reserves as a solution for its dependence on importing fuel. The 2014 coal reserves data from the Geological Agency, Ministry of Energy and Mineral Resources is about 124.8 billion tons and its proven reserves are about 32.27 billion tons. In general, those reserves mines found until $300 \mathrm{~m}$ in depth and can be mined in an open or underground mining. The geological analysis estimates that the potential reserve remains quite large till the depth of $1.000 \mathrm{~m}$ and is expected to reach 280 billion tons. However, about 119 billion tons are not suitable for conventional mined. These potential reserves are expected to be developed for underground gasification. It is considered that the underground mine is a better technique rather than that of the conventional ones. Referring to the National Energy Council, coal will be one of the important fuel in the future because it can provide $25 \%$ supply of national energy in 2050.

Indonesia coal has an important role not only as a fuel, but also as an export commodity. It was quite large and reached 32.27 billion tons on January 1, 2014. Indonesia coal is environmentally friendly due to the low ash and sulfur. The coal mine location is near the coast or rivers and results in easy to handle the product. These advantages make Indonesian coal is more competitive in the world market (Sugiyono et al., 2016).

Reserve calculation of the UCG area is limited to coal seam D with the depth of 200 till $300 \mathrm{~m}$ (Figure 6.). The resource value was about 9.08 million tons. This includes the measured, designated and inferred resources (Purnama et al., 2017).

In general, there are 11 coal seams in the UCG project area as a continuity of Muara Enim formation. Those are L, K, J, H1, H2, G1, G2, F, E, DA and D seams. The coal target locates in seam $D$. The seam $D$ is classified as a low-rank coal characterized by lignite to sub-bituminous. It has a calorific value in the range of $4900-6300 \mathrm{kcal} / \mathrm{kg}$. The ash content is about $1.8-4.9 \%$ and the moisture content is around $29.2-44.6 \%$. Based on the UCG requirement, seam D qualifies the UCG process.

Rock overlying a mineral deposit is in a natural equilibrium state. Unsupported mine voids created during underground mining 
will cause instability within the rocks and lead to their displacement and deformation (Orlov, 2018). Geotechnical evaluation of the UCG project area as well as physical and mechanical characteristics of the core samples, the site had been evaluated using a simple model of Ansy's software version 16 to review the rock performance. It focused on the rock strength, which flanks the targeted coal for UCG process, through the thermal influence during coal gasification. From the model point of view, the research project location shows that the increase of rocks thickness will decrease the deformation during coal gasification (Zulfahmi, 2017). Further modelling including modelling the material and thermal load condition of rock will be tested in detailed.

Based on the previous studies that had been held in other countries; to recognize the environmental risk of UCG activity, it must be generally identified the possible hazard causes the environmental risk. Indonesian UCG research project is mostly susceptible with some hazards in its all activities. The hazard is defined as the property of a substance or situation with the potential to create damages while the risk is defined as a specific effect within a specified period (as a complex function of probability, consequences, and vulnerability.

In this study, the potential of groundwater contamination becomes the main hazard that should be taken into account from the beginning. Other major concerns in the UCG potential risks are releasing the product gases (especially the combustible gases), transporting the contaminant and the impact of groundwater as a resource. For the UCG, risk potentials depend on the geological condition and the chosen technology that will be implemented in the project area. In the Indonesian UCG research project point of view, for successful project scenario, the UCG activities should meet not only the production requirement but also should maintain the safety standard for all activities concerned. For a preliminary study, the project was started by having a flare to prove that the technology could be implemented in this site.

UCG gasifiers are always located in a saturated zone beneath the local water table. Because the cavity gas pressure is typically operated below hydrostatic pressure, the water will flow into the cavity, convert to the steam, and be consumed in the gasification reactions. If too much water flows in, however, the coal will extinguish and the cavity will be flooded. The rate of influx is controlled by the local permeability and the cavity gas pressure. Over time, the consumption of water will also lead to a decline in hydraulic head measurements in monitoring wells surrounding the cavity. A detailed understanding of the local hydrology is therefore essential for developing a good operation and monitoring plan (Camp and White, 2015).

Based on the geo-electricity resistivity method for predicting the groundwater saturated zone on rock surrounding the UCG area, there is an indication that the average of the non-saturated zone is below $5 \%$. It means that the majority of rocks in the investigated UCG area is characterized as possibly saturated groundwater zone or consists of the clay layer. All layers of rocks beneath the surface in those area also consist of groundwater saturated rock which mainly composed of clay (Pujianto and Nugroho, 2017). Considering the above condition, the baseline data for groundwater quality must be prepared in detail.

If the cavity is operated below a hydrostatic pressure, the water influx will tend to flush contaminants towards the cavity and minimize the groundwater contamination risk. At the end of the operation, the cavity can then be flushed to minimize the contaminant migration after the wells are shut-in and the cavity floods. Gas-quality can often be improved by operating highcavity pressures, so there is an economic incentive to operate the cavity as close to hydrostatic pressure as possible. A critical observation, however, occurs if the cavity gas operating pressure exceeds the hydrostatic, the gas can be pushed away from the cavity into the formation.

\section{Potential Hazards at Proposed UCG Pilot Project}

In Indonesian UCG research project point of view, a technology choice will determine the risk condition. Due to the dominant environmental risk result subsidence and reducing water quality, then, the effects on water environment especially in the 
groundwater contamination will be discussed in detail. To recognize the environmental risk in a certain activity, it generally must be started by identifying and characterizing the pollutant which will come out from the activity.

The interaction between the UCG and its environment is shown in Figure 4. Field tests in some countries which demonstrated repeatedly shows that the risk of groundwater contamination is real of UCG problem beside subsidence and roof collapse (Camp, 2018). By monitoring and controlling the air in the vulnerable area, the real danger of explosion and poisoning could be evaluated by the simulation model, so it is possible to reduce this risk (Kostúr, Laciak and Durdan, 2018). The proposed UCG system and all associated works supported, require a planning which must follow the existing environmental regulation, especially for coal, because specific regulation concerns in UCG technology has not existed yet. The predicted hazards could include landscape/visual; dust; noise; surface water and groundwater; air quality and land quality/contaminated land.

Physically, a 5-Ha land clearing will cause changes of the landscape surrounding the UCG pilot project in South Sumatera. The equipment mobilization will also influence the area, especially during the dry season. Dust and noise will reduce air quality. This condition can be controlled by rescheduling and keeping off the activities at the dry season. Dust can be managed by watering the road while equipment mobilization is ongoing. When developing the UCG project, land clearing is not as big as those happened in conventional mining. As a result, dust may not annoy much in this activity however it remains to be considered for the future.

Drilling activities for geological survey, injection or production wells have a potential to contaminate the surface water and groundwater. Drilling operation will cause cross contamination of the aquifer horizon and generate solid and liquid waste. The contaminants come from the drilling fluids are known as water-based mud or oil-based mud. Generally, the former is more preferred than the later due to its environmentally friendly character and less cost. Types of drilling mud used must consider some conditions like the nature of strata formation such as the existence of aquifer, the depth of the wells, the angle of its deviation, etc. Wells must be designed and constructed to ensure its integrity during drilling and after its operations. The purpose is to eliminate the leakage caused by injection agents or product gases. When vertical well drilling is in progress, borehole stability must be ensured to prevent groundwater inflow that can cause cross contamination. The inflow of groundwater can be prevented by controlling the hydrostatic head pressure that is arranged greater than that of the geological formation pressure. Indonesian UCG pilot project used bentonite for drilling mud. Such a polymer was also used as the additive for certain purposes. It should be noticed for the drilling mud whether the material was appropriate for the drilling purpose or not. Basic drilling mud generally comprises of water or oil, bentonite for increasing viscosity, barite for increasing density, sodium hydroxide or soda ash for $\mathrm{pH}$ control and potassium chloride as an inhibitor of the degradation clay formation. Those constituents are chemically inert. To ensure the condition, the produced drilling fluid must be checked if there are no differences significantly from surface water or groundwater (Sury et al., 2004).

Other potential hazards that may influence waters could be come from UCG process. There is no risk coming from the 'running out of control' deep UCG process because the coal cannot be either burned or gasified in the absence of oxygen. The UCG system will be cooled down when the injected oxygen through injection well is terminated. For quenching the gasifier, the additional facility must be built for injecting nitrogen and water. Hence, effective process control will be the key to either efficient UCG operation or minimum potential contaminants generation and dispersion. If the control condition cannot be fulfilled, there will be some consequences such as gas losses and other fluids leakage.

Gas lost and fluid leakage could be as the potential hazards because it will influence significantly to the environment and produce pollution to either the air or water bodies. In the UCG, there is no need for disposing the waste from either the product or the coal ash above the ground (Coil, McKittrick and Higman, 2014). For this purpose, the 
RDCMCT had conducted a baseline survey to monitor the air, soil, sediment and water quality, including the surface water and groundwater quality. There are 18 soil samples, 7 air samples, 36 water samples, and 8 sediment samples. Musi subwatershed must receive attention because the location of the UCG activity is in this area (Figure 7).
Generally, the environmental quality is in good condition, even though there are some irrelevancies between parameters of environmental quality and the referenced standards. For the environment quality assessment, the list of the reference standard is presented in Table 3.

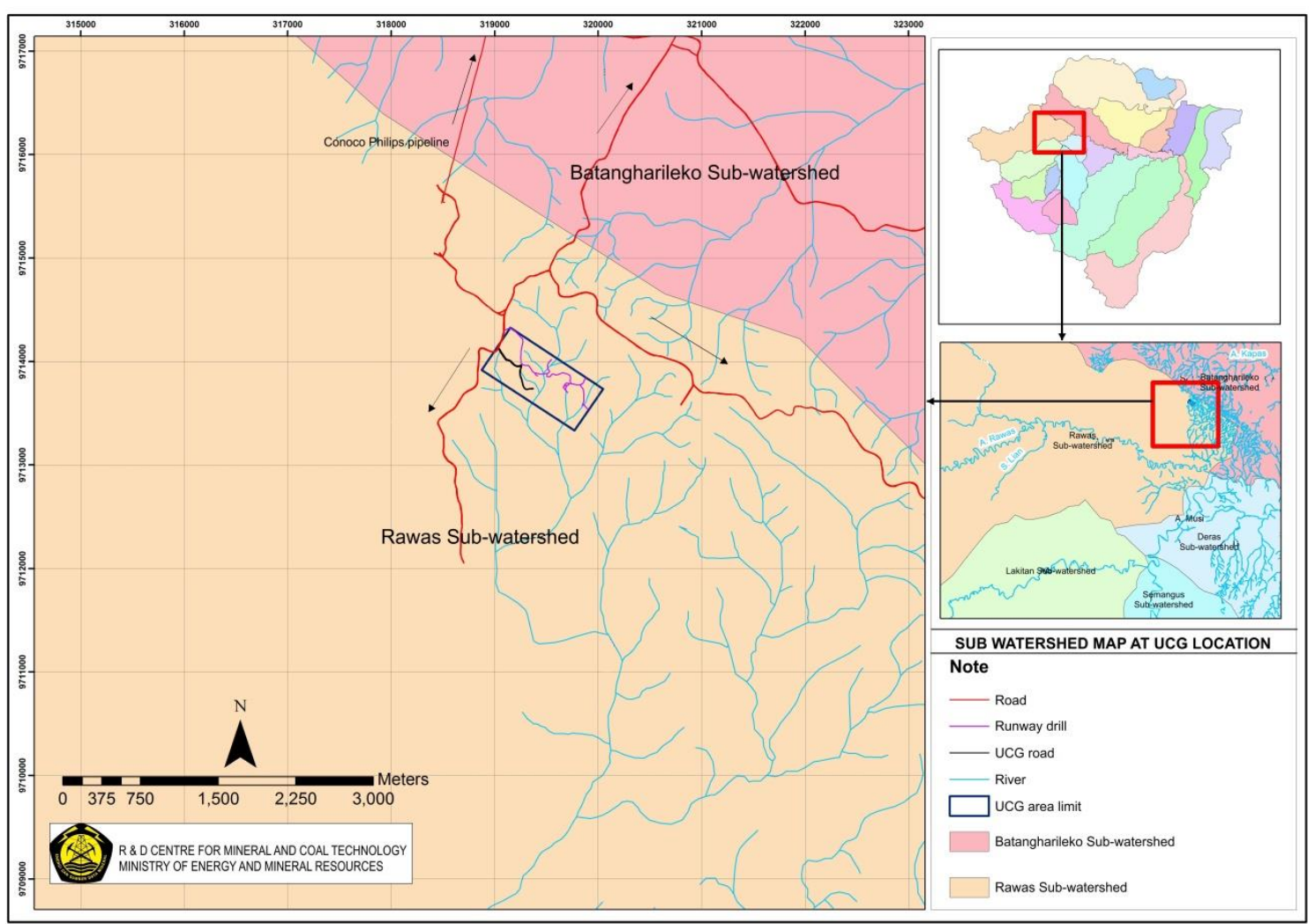

Figure 7. Indonesia UCG research project at the Musi Watershed (modified from BPS, 2010)

Table 3. Reference used for the environmental quality assessment

\begin{tabular}{|c|c|c|}
\hline No. & References & Remarks \\
\hline 1 & Government Regulation No. 41/1999 & Control of Air Pollution \\
\hline 2 & Government Regulation No. 82/2001 & $\begin{array}{l}\text { Water Quality Management and Water Pollution } \\
\text { Control - Class III }\end{array}$ \\
\hline 3 & $\begin{array}{l}\text { Ministerial Decree on Environment and } \\
\text { Forestry No. 48/MENLH/11/1996 }\end{array}$ & Standard Quality of Noise Level \\
\hline 4 & $\begin{array}{l}\text { Ministerial Decree on Labor No. } \\
51 / \mathrm{MEN} / 1999\end{array}$ & $\begin{array}{l}\text { The Threshold Values of Physical Factors and } \\
\text { Chemical Factors In The Workplace }\end{array}$ \\
\hline 5 & $\begin{array}{l}\text { Ministerial Regulation on Health No. } \\
\text { 416/Men-Kes/PER/IX/1990 }\end{array}$ & $\begin{array}{l}\text { Quality Standards of Clean Water } \\
\text { Requirements }\end{array}$ \\
\hline 6 & $\begin{array}{l}\text { Ministerial Regulation on Health No. } \\
\text { 492/Men-Kes/PER/IX/2010 }\end{array}$ & $\begin{array}{l}\text { Quality Standards for Drinking Water } \\
\text { Requirements }\end{array}$ \\
\hline
\end{tabular}


The soil types dominate the study location at Musi Banyuasin area consisting of gley alluvial and latosol. The condition informs that the soil having low fertility. Physical analysis on soil properties indicates that $98 \%$ of mine soil composed of sand. At the hauling road, the soil is dominated by clay (about $42 \%$ ) showing good enough bulk density and its porosity is more than $41 \%$. It classified as the loose soil. The chemical properties show that the soil has low $\mathrm{pH}(4.50-5.67)$ that means it is in acid condition and would limit the microbial activity. The ideal soil $\mathrm{C} / \mathrm{N}$ ratio is about 24 , but in this area, $\mathrm{C} / \mathrm{N}$ ratio is in the range of $82.65-$ 152.08. This means that the high $\mathrm{C}$ material dominates the mine area. This also means that there is not sufficient $\mathrm{N}$ for growing the microbial population optimally. It is indicated by low $\mathrm{N}$ concentration in the soil $(0.098-$ $0.52 \%$ ), so it will make soil degradation proceed in a certain rate. The soil moisture content was good enough. As $98 \%$ of mine soil composed of sandy soil, this will be a good drainage but its holding capacity for water and nutrient become low. It also corresponds to the value of cation exchange capacity (CEC) which is also low. The low CEC $(<10$ me/ $100 \mathrm{~g}$ ) indicates that the soils prone to leaching and nutrient loss; maintaining the essential organic matter and having low water holding capacity. The medium CEC (10 - 15 me/ $100 \mathrm{~g}$ ) shows the typical range for loam soil that has moderate nutrient and water holding capacity. For the high CEC soil (> 20 $\mathrm{me} / 100 \mathrm{~g}$ ), it is typical of heavy clay soil and organic peat with high nutrient and water holding capacity (Cotching, Brown and Lemon, 2018). Soil quality parameter at the proposed UCG location is presented in Table 4.

Air quality at the study area covers parameters of noise, hydrocarbon $(\mathrm{HC})$, carbon monoxide $(\mathrm{CO})$, ozone $\left(\mathrm{O}_{3}\right)$, sulfur dioxide $\left(\mathrm{SO}_{2}\right)$, nitrogen dioxide $\left(\mathrm{NO}_{2}\right)$, particulate $\left(\mathrm{PM}_{10}\right.$ and $\left.\mathrm{PM}_{2.5}\right)$, dust (total suspended particulate/TSP) and lead $(\mathrm{Pb})$. Different rank coals produce different amounts of $\mathrm{CO}_{2}$ per million BTU (Bowen and Irwin, 2008). The baseline sampling area was conducted at surrounding UCG pilot project area. Noise in this UCG pilot project is higher than that of the noise in the settlement area. The ambient air quality in this location shows that there has not been polluted yet, indicates that almost all measured parameters are below the threshold value. Ambient air quality parameters at the surrounding proposed UCG pilot project are presented in Table 5.

Table 4. Baseline of soil quality at the UCG location

\begin{tabular}{clcc}
\hline No. & \multicolumn{1}{c}{ Parameter } & Unit & Concentration \\
\hline 1 & $\mathrm{pH}\left(\mathrm{H}_{2} \mathrm{O}\right)$ & - & $4.50-5.67$ \\
2 & $\mathrm{pH}(\mathrm{KCl})$ & - & $3.76-4.17$ \\
3 & Moisture content & $\%$ & $8.11-30.07$ \\
4 & C-org & $\%$ & $1.33-6.06$ \\
5 & $\mathrm{~N}$-total & $\%$ & $0.098-0.52$ \\
6 & $\mathrm{CEC}$ & $\mathrm{me} / 100 \mathrm{~g}$ & $2.51-22.51$ \\
7 & $\mathrm{P}_{2} \mathrm{O}_{5}(\mathrm{HCl} \mathrm{25 \% )}$ & $\mathrm{mg} / 100 \mathrm{~g}$ & $<0.01-21.39$ \\
8 & $\mathrm{~K}_{2} \mathrm{O}(\mathrm{HCl} \mathrm{25 \% )}$ & $\mathrm{mg} / 100 \mathrm{~g}$ & $6.85-45.49$ \\
9 & $\mathrm{~K}-\mathrm{exch}$ & $\mathrm{me} / 100 \mathrm{~g}$ & $0.031-0.505$ \\
10 & $\mathrm{Na}-e x c h$ & $\mathrm{me} / 100 \mathrm{~g}$ & $0.063-0.531$ \\
11 & $\mathrm{Ca}-\mathrm{exch}$ & $\mathrm{me} / 100 \mathrm{~g}$ & $0.014-1.1$ \\
12 & $\mathrm{Mg}$-exch & $\mathrm{me} / 100 \mathrm{~g}$ & $0.079-1.02$ \\
\hline
\end{tabular}

Table 5. Baseline of ambient air quality at the UCG location

\begin{tabular}{clcc}
\hline No. & \multicolumn{1}{c}{ Parameter } & Unit & Concentration \\
\hline 1 & Hydrocarbon $(\mathrm{HC})$ & $\mu \mathrm{g} / \mathrm{Nm}^{3}$ & $<1$ \\
2 & Carbon monoxide $(\mathrm{CO})$ & $\mu \mathrm{g} / \mathrm{Nm}^{3}$ & $360-2951$ \\
3 & Ozone $\left(\mathrm{O}_{3}\right)$ & $\mu \mathrm{g} / \mathrm{Nm}^{3}$ & $8-81$ \\
4 & Sulfur dioxide $\left(\mathrm{SO}_{2}\right)$ & $\mu \mathrm{g} / \mathrm{Nm}^{3}$ & $<3.081$ \\
5 & Nitrogen Dioxide $\left(\mathrm{NO}_{2}\right)$ & $\mu \mathrm{g} / \mathrm{Nm}^{3}$ & $10-15$ \\
6 & Particulate $\left(\mathrm{PM}_{10}\right)$ & $\mu \mathrm{g} / \mathrm{Nm}^{3}$ & $48-95$ \\
7 & Particulate $\left(\mathrm{PM}_{2.5}\right)$ & $\mu \mathrm{g} / \mathrm{Nm}^{3}$ & $27-43$ \\
8 & Dust $(\mathrm{Total}$ Suspended Particulate/TSP) & $\mu \mathrm{g} / \mathrm{Nm}^{3}$ & $53-141$ \\
9 & Lead $(\mathrm{Pb})$ & $\mu \mathrm{g} / \mathrm{Nm}^{3}$ & $<0.26$ \\
10 & Noise & $\mathrm{dBA}$ & $56-57$ \\
\hline
\end{tabular}


The environment baseline for waters, either the surface water or groundwater, also represents the unpolluted condition. Some parameters (BOD and $C O D)$ in river waters are above the river water quality standards for the class 3 rivers. Generally, the water quality can still support the aquatic biota life. Other parameters such as nutrient content (nitrogen and phosphorus) are also below the water quality standard. High total organic compounds were found in the rivers due to the decomposition of natural and synthetic organic matter nearby. The TOC plays a role in assessing the potential for water pollution caused by organic matter pollutant. Phenol, benzene, toluene, ethylbenzene, xylene or BTEX and polycyclic aromatic hydrocarbons (PAHs) are undetectable in the river water. Since 2016, there were 22 sampling points that have been surveyed. The sampling locations include the river waters for fisheries, livestock, irrigation, and other utilization. The river waters include Lintang, Anak Lintang, and Ampalau. The physical and chemical water quality parameters are presented in Table 6.

Other UCG's major problem is that the public would probably perceive it as a highrisk system which has a potential for deleterious effects in terms of health and safety to the local community and the environment. For the purpose of developing UCG project in Indonesia, a study on public perceptions must be conducted because some concerns will be usually raised related to the fear of the uncontrolled combustion, pollutant escape to the environment, groundwater contamination and subsidence. Planning and public perception could impose significant restraints on the exploitation of UCG in rural areas (Shackley, Reiche and Mander, 2004).

Table 6. Water quality of rivers and wells around UCG activities

\begin{tabular}{|c|c|c|c|c|}
\hline \multirow{2}{*}{ No. } & \multirow{2}{*}{ Parameters } & \multirow{2}{*}{ Units } & \multicolumn{2}{|c|}{ Concentration } \\
\hline & & & River & Well \\
\hline 1 & Temperature & ${ }^{\circ} \mathrm{C}$ & $25.8-34.3$ & $29.2-32.3$ \\
\hline 2 & Conductivity & $\mu \mathrm{S} / \mathrm{cm}$ & $6.7-2951$ & $24.42-186.1$ \\
\hline 3 & Total Suspended Solids (TSS) & $\mathrm{mg} / \mathrm{l}$ & $2.9-225.29$ & $7.6-44.6$ \\
\hline 4 & Total Dissolved Solids (TDS) & $\mathrm{mg} / \mathrm{l}$ & $3.9-40.7$ & $12.47-91.74$ \\
\hline 5 & $\mathrm{pH}$ & - & $4.6-5.55$ & $4.95-6.24$ \\
\hline 6 & Acidity & - & - & $59.7-254$ \\
\hline 7 & DO & $\mathrm{mg} / \mathrm{l}$ & $1.5-6.73$ & $0.6-4.83$ \\
\hline 8 & BOD & $\mathrm{mg} / \mathrm{l}$ & $0.26-5.08$ & $0.12-0.57$ \\
\hline 9 & COD & $\mathrm{mg} / \mathrm{l}$ & $0.99-23.4$ & $2.55-13.41$ \\
\hline 10 & $\mathrm{~N}-\mathrm{NH}_{4}$ & $\mathrm{mg} / \mathrm{l}$ & $<0.077-0.33$ & - \\
\hline 11 & $\mathrm{~N}-\mathrm{NO}_{2}$ & $\mathrm{mg} / \mathrm{l}$ & $<0.002-0.003$ & $0.003-0.004$ \\
\hline 12 & $\mathrm{~N}-\mathrm{NO}_{3}$ & $\mathrm{mg} / \mathrm{l}$ & $0.02-0.18$ & $0.086-0.533$ \\
\hline 13 & $P$ & $\mathrm{mg} / \mathrm{l}$ & $<0.001-0.085$ & $0.005-0.219$ \\
\hline 14 & $\mathrm{Cl}^{-}$ & $\mathrm{mg} / \mathrm{l}$ & - & $3.59-5.69$ \\
\hline 15 & $\mathrm{SO}_{4}{ }^{2-}$ & $\mathrm{mg} / \mathrm{l}$ & - & $11.26-12.32$ \\
\hline 16 & Barium (Ba) & $\mathrm{mg} / \mathrm{l}$ & $0.017-0.69$ & $0.01-0.164$ \\
\hline 17 & Aluminum (Al) & $\mathrm{mg} / \mathrm{l}$ & $0.004-1.48$ & $<0.001-0.349$ \\
\hline 18 & Cadmium (Cd) & $\mathrm{mg} / \mathrm{l}$ & $<0.005-<0.029$ & $<5$ \\
\hline 19 & Cobalt (Co) & $\mathrm{mg} / \mathrm{l}$ & $<0.130$ & $<0.130$ \\
\hline 20 & Chromium $\left(\mathrm{Cr}^{6+}\right)$ & $\mathrm{mg} / \mathrm{l}$ & $0.002-<0.01$ & $0.001-0.009$ \\
\hline 21 & Iron $(\mathrm{Fe})$ & $\mathrm{mg} / \mathrm{l}$ & $<0.046-0.972$ & $0.159-7.05$ \\
\hline 22 & Manganese (Mn) & $\mathrm{mg} / \mathrm{l}$ & $<0.051-0.113$ & $<0.051-1.07$ \\
\hline 23 & Copper (Cu) & $\mathrm{mg} / \mathrm{l}$ & $0.008-0.104$ & - \\
\hline 24 & Lead $(\mathrm{Pb})$ & $\mathrm{mg} / \mathrm{l}$ & $<4.846-26.84$ & $<4.486-5.852$ \\
\hline 25 & Zinc $(\mathrm{Zn})$ & $\mathrm{mg} / \mathrm{l}$ & $<0.019-0.034$ & $<0.019-0.069$ \\
\hline 26 & Nickel (Ni) & $\mathrm{mg} / \mathrm{l}$ & $<0.045$ & $<0.045$ \\
\hline 27 & Mercury $(\mathrm{Hg})$ & $\mathrm{mg} / \mathrm{l}$ & $<0.24-5.04$ & - \\
\hline 28 & Arsenic (As) & $\mathrm{mg} / \mathrm{l}$ & $<1.39-87.8$ & $<1.39$ \\
\hline 29 & Selenium (Se) & $\mathrm{mg} / \mathrm{l}$ & $<0.001-0.004$ & $0.002-0.004$ \\
\hline
\end{tabular}


Then, it is followed by how to remedy the environment by looking forward to the possibility of pollutant dispersion in the environment. Hazards coming from the UCG processes which commonly discuss are as follow:

- resources contamination on surface water and groundwater;

- problems in water supply quantity;

- environmental aspect;

- health aspects;

- economic aspects.
Though several environmental issues will be avoided on the UCG, such as generation of spoil, handling waste water etc., but there is also UCG issues related to its technology.

For the Indonesia UCG Pilot Project, hazard identification only discussed the global condition coming from the technical operation, especially those are linked with the baseline existing condition.

Table 7. Identification hazards from underground coal gasification (Beath et al., 2004; The Working Group on UCG, 2007; Ag Mohamed et al., 2011; Self, Reddy and Rosen, 2012)

\begin{tabular}{|c|c|c|c|}
\hline No. & $\begin{array}{c}\text { Hazards } \\
\text { Description }\end{array}$ & Initiating Event Likelihood & Risk Class \\
\hline 1 & Subsidence & $\begin{array}{l}\text { - the extent of subsidence at ground level during the } \\
\text { abroad gasification trials has been rarely published. } \\
\text { - at the time of the tests the subsidence may not } \\
\text { have been evident, however, later observations } \\
\text { showed that subsidence occurred as potholing at } \\
\text { some of the sites. } \\
\text { - the groundwater contamination issues discussed } \\
\text { above certainly suggest that subsidence should } \\
\text { have been noticeable, considering the extreme } \\
\text { disruption of aquifers at some sites. } \\
\text { - the subsidence could be due to the shallow seams } \\
\text { being utilized during UCG process. } \\
\text { - overall, in a well-designed and tightly controlled } \\
\text { gasification site it would be likely that subsidence } \\
\text { would be similar to that expected after longwall } \\
\text { mining of the same coal seams at the same depth. } \\
\text { It is unlikely that the thermal effects of gasification on } \\
\text { the overlying rock strata would lead to considerably } \\
\text { greater subsidence. }\end{array}$ & $\begin{array}{c}\text { Medium to } \\
\text { High }\end{array}$ \\
\hline 2 & $\begin{array}{l}\text { Groundwater and } \\
\text { surface water } \\
\text { contamination }\end{array}$ & $\begin{array}{l}\text { - it was predicted that the contamination occurred due to } \\
\text { the excessive pressures during some stages of the } \\
\text { tests } \\
\text { - it led to organic or inorganic contaminant which forced } \\
\text { out }\end{array}$ & $\begin{array}{c}\text { Medium to } \\
\text { High }\end{array}$ \\
\hline 3 & $\begin{array}{l}\text { Contaminated } \\
\text { water }\end{array}$ & $\begin{array}{l}\text { - the volume of wastewater should be more less than } \\
\text { from conventional mining but the stream from the gas } \\
\text { scrubbers will include a high concentration of organics, } \\
\text { such as phenols }\end{array}$ & $\begin{array}{l}\text { Medium to } \\
\text { High }\end{array}$ \\
\hline 4 & Air quality & $\begin{array}{l}\text { - potential air pollution that influences the air quality } \\
\text { comes from carbon dioxide and water vapour } \\
\text { - the combustion of product gas contribute the air } \\
\text { pollution results } \\
\text { - the standard bituminous coal will produce water } \\
\text { vapour, } \mathrm{CO}_{2}, \mathrm{CO}, \text { methane, hydrogen, hydrogen } \\
\text { sulfide and hydrogen chloride if it is not treated well }\end{array}$ & $\begin{array}{l}\text { Medium to } \\
\text { High }\end{array}$ \\
\hline 5 & $\begin{array}{l}\mathrm{CO}_{2} \text { Emission and } \\
\text { Carbon Capture }\end{array}$ & $\begin{array}{l}\text { - coal as fossil fuel will emit highest carbon dioxide while } \\
\text { the combustion process compares to other fossil fuels. } \\
\text { - the carbon storage implementation has potential in } \\
\text { greenhouse gas emissions reduction. } \\
\text { - naturally, leakage had been documented from the } \\
\text { natural } \mathrm{CO}_{2} \text { reservoir, so these can also happen in the } \\
\text { carbon storage site }\end{array}$ & $\begin{array}{l}\text { Medium to } \\
\text { High }\end{array}$ \\
\hline
\end{tabular}


The risk of groundwater contamination in the UCG activities generally comes from:

- the hot product gases escaping from cavity zone during the coal burning;

- the contaminant leaching caused by water filling in the gasification cavity;

- gasification collapses caused by coal to aquifer connection.

The groundwater contamination will be a serious environmental problem. The degradation can be originated from the organic contaminant in tars, trace elements containing inorganic salts in the ash leachate and interconnection of aquifer caused by fracturing or subsidence (Verma et al., 2014). In the laboratory testing, tar samples showed organic contaminants that could become out during UCG operation. The tar sample had been identified as organic compounds like phenols, PAHs and BTEX. Based on the data, the study of Indonesia UCG pilot project must observe more closely the surrounding location of the activity against the presence of these organic compounds.

\section{CONCLUSIONS AND SUGGESTIONS}

In Indonesia, the UCG development is categorized as an extreme and new energy process technology due to its unpredictable operational condition. It is important to control the physical and chemical mechanisms which might occur at UCG model plants.

Research organizations or universities must conduct projects \& studies funded by the government agencies and/or private business groups to develop UCG technology simulator facilities in the designed laboratory along with the real life of planned pilot projects.

Selecting the best technological procedure is an important variable function that depends on real factors. Indonesia has to raise their facts figure and find out the problems and issues so that the suitable technology could be developed by considering some obstacles for developing commercial operation of coal gasification. For this purposes, the research organization should also develop the detail demonstrated technology which equipped with some sensors to have a description that close to reality.

The critical problems in Indonesia are the subsidence and water inflow in the gasification chamber. So, a detailed 3D model related to thermal - mechanical condition surrounding UCG cavities should be able to be demonstrated and simulated. The model must be able to simulate the heat propagation, stress distribution and probability of surface subsidence in the location of UCG process. Other model should be developed using computational fluid dynamics (CFD) environment software to investigate the effect of some parameters on the UCG process.

Generally, for the future development of the Indonesia UCG Project, some numerical models must be constructed in detail for the purpose of getting the accurate namely by:

- predicting groundwater flow rate into UCG cavities as long as the project operation;

- changing the subsurface environment during UCG operation;

- migrating the contaminant from the UCG panel;

- gathering subsidence data on the surface;

- evaluating sensitivity and uncertainty during the prediction process.

In the interest of UCG techniques development, some fast track approaches could be developed by private companies to set up a demonstration or semi-commercial UCG projects regarding utilization of deepseated coal and lignite deposits. Such incentives might be considered for pioneer of UCG development to encourage a partnership.

To evaluate the potential application of technology in detail, it requires a strong effort from the $R$ and $D$ institution, especially in concern of geological subsurface and geomechanical characterization, combustion process modelling and environmental risk assessment.

To gain a good result in developing UCG project, it is suggested to :

- applying and measuring the integrated original designs which will make them possible to obtain technology-efficient 
methods for generating energy in the UCG process;

- implementing a method that is assumed to be able to stabilize the pressure in a geo-reactor that allows to operate the underground installation section safely;

- maintaining the concentration of toxic components (i.e.: $\mathrm{CH}_{4}, \mathrm{CO}$, and $\mathrm{H}_{2}$ ) not to exceed the threshold value during UCG activities;

- preparing and recording the operation procedures for underground gasification plants based on the operational and exploitation data as a standard if the same type of implemented industrial process is applied;

- testing the UCG process in the laboratory or modeling installation, because the thermal problems in industrial conditions and typical events for real industrial processes are difficult to be predicted. Further detailed research is needed to prolonged gasification in the condition of process operations;

- monitoring the oxygen in the process to watch no leakage in the process.

- using the multiple hazard analysis techniques because each analysis has its own purpose, strengths, and weaknesses for risks assessment. The combined techniques must be considered for risk assessment

\section{ACKNOWLEDGEMENT}

The authors would like to acknowledge the RDCMCT for funding the research and PT. Astaka Dodol for permitting to conduct the research in this project area. The author is also grateful all research team members.

\section{REFERENCES}

Ag Mohamed, A., Batto, S. F., Changmoon, Y., Chien, S. C., Choe, J. I., Cole, K. R., Engel, K., Gardner, W., Gilbert, S. N., Hui, Y., Israel, K. J., Kellogg, A. L., Kurniawaty, E. T., Labovitz, L. R., Lee, J., Liang, S., Lostroscio, K. L., Malcore, J., Mendivil, C., Murray, S. J., Neary, R. K., Otto, Z. L., Panchenko, N., Patton, D. N., Priddis, T. L., Saunders, J. E. L., Saunders, R., Schory, D. K., Scroggins, K. P., Skaggs, J. E., Symonenko, L. G. and Wisely, A. M. (2011) Viability of underground coal gasification with carbon capture and storage in Indiana.
Edited by E. Baldwin, K. Richards, J. Rupp, M. Mastalerz, J. Schumacher, and S. Carley. School of Public and Environmental Affairs. Available at: http://www.indiana.edu/ cree/pdf/Viabilit $y$ of Underground Coal Gasification Report.pdf.

Beath, A., Craig, S., Littleboy, A., Mark, R. and Mallett, C. (2004) Underground coal gasification: Evaluation environmental barriers, Queensland, Australia: CSIRO. Available at: https://publications.csiro.au/rpr/downloa d?pid=legacy:2099\&dsid=DS1.

Blinderman, M. S., Saulov, D. N. and Klimenko, A. Y. (2008) "Forward and reverse combustion linking in underground coal gasification," Energy, 33(3), pp. 446454. doi: 10.1016/j.energy.2007.10.004.

Bowen, B. H. and Irwin, M. W. (2008) Underground coal gasification. CCTR basic facts file: Indiana Center for Coal Technology Research.

BPS (2010) Buku putih sanitasi Kabupaten Musi Banyuasin, ppsp.nawasis.info.

Burton, E., Friedmann, J. and Upadhye, R. (2007) Best practices in underground coal gasification. California: Lawrence Livermore National Laboratory. Available at:

https://www.purdue.edu/discoverypark/e nergy/assets/pdfs/cctr/BestPracticesinU CG-draft.pdf.

Camp, D. W. (2018) "Underground coal gasification research and development in the United States," in Blinderman, M. S. and Klimenko, A. Y. (eds.) Underground Coal Gasification and Combustion. Elsevier, pp. 59-127. doi: 10.1016/B978-0-08-100313-8.00004-9.

Camp, D. W. and White, J. A. (2015) Underground coal gasification: An overview of groundwater contamination hazards and mitigation strategies (LLNLTR-668633). Lawrence Livermore National Laboratory. Available at: https://e-reports-

ext.Ilnl.gov/pdf/790296.pdf.

Coaltrans Conferences (2014) Coal map Indonesia, www.coaltrans.com. Available at: http://www.coaltrans.com/pdfs/Coal_Ma p_Indonesia.pdf (Accessed: January 17, 2017). 
Coil, D., McKittrick, E. and Higman, B. (2014) Underground coal gasification (UCG), www.groundtruthtrekking.org. Available at:

http://www.groundtruthtrekking.org/lssue s/AlaskaCoal/UndergroundCoalGasificat ion.html (Accessed: January 16, 2018).

Cotching, B., Brown, K. and Lemon, J. (2018) Cations and cation exchange capacity, www.soilquality.org.au. Available at: http://www.soilquality.org.au/factsheets/c ation-exchange-capacity (Accessed: June 12, 2018).

Imran, M., Kumar, D., Kumar, N., Qayyum, A., Saeed, A. and Bhatti, M. S. (2014) "Environmental concerns of underground coal gasification," Renewable and Sustainable Energy Reviews, 31, pp. 600-610.

doi: 10.1016/j.rser.2013.12.024

Khan, M., Mmbaga, J., Shirazi, A., Trivedi, J., Liu, Q. and Gupta, R. (2015) "Modelling underground coal gasification - A review," Energies, 8(11), pp. 1260312668. doi: $10.3390 /$ en81112331.

Kostúr, K., Laciak, M. and Durdan, M. (2018) "Some influences of underground coal gasification on the environment," Sustainability, 10(5), p. 1512. doi: $10.3390 /$ su10051512.

Krause, S. (2011) Hydro-geological implication of underground coal gasification environmental risk assessment. Keele University - UK. Available at: http://repository.icse.utah.edu/dspace/bit stream/123456789/11034/1/skrause_ug cp_2011.pdf.

Mocek, P., Zamiar, R., Jachimczyk, R., Gowarzewski, R., Świądrowski, J., Gil, I. and Stańczyk, K. (2015) "Selected issues of operating $3 \mathrm{MW}$ underground coal gasification installation," Eksploatacja i Niezawodnosc. Maintenance and Reliability, 17(3), pp. 427-434. doi: 10.17531/ein.2015.3.14.

Mohanty, D. (2017) "An overview of the geological controls in underground coal gasification," IOP Conference Series: Earth and Environmental Science, 76(012010), pp. 1-9. doi: 10.1088/17551315/76/1/012010.

Monk, F., Hallowes, D., Moore, K. and Ross, L. (2016) Fueling the fire: The chequered history of UCG and coal chemicals around the world. Edited by M. Church,
R. Dixon, and S. Shaw. Amsterdam: Friends of the Earth International. Available at: https://www.foei.org/wpcontent/uploads/2016/07/FoEl_Fuelling_ the_Fire_July2016.pdf.

Moorhouse, J., Huot, M. and McCulloch, M. (2010) Underground coal gasification: Environmental risks and benefits. Edited by R. Franchuk. Alberta, Canada: The Pembina Institute. Available at: https://www.pembina.org/reports/laurusr eport.pdf.

Orlov, G. V. (2018) "The effects of rock deformation in underground coal gasification," in Blinderma, M. S. and Klimenko, A. Y. (eds.) Underground Coal Gasification and Combustion. Elsevier, pp. 283-327. doi: 10.1016/B978-0-08100313-8.00010-4

Pujianto, E. and Nugroho, A. (2017) "Prediksi zona jenuh airtanah pada batuan di areal pilot plant underground coal gasification, Musi Banyuasin, Sumatera Selatan," Jurnal Teknologi Mineral dan Batubara, 13(3), pp. 171-183.

doi: 10.30556/jtmb.Vol13.No3.2017.176.

Purnama, A. B., Subarna, Y. S., Sendjadja, Y. A., Muljana, B. and Santoso, B. (2017) "Potensi batubara untuk pengembangan gasifikasi bawah permukaan: Studi kasus Desa Macang Sakti, Provinsi Sumatera Selatan," Jurnal Teknologi Mineral dan Batubara, 13(1), pp. 13-30. doi: 10.30556/jtmb.Vol13.No1.2017.156.

Rosso Murillo, J. W. (2013) "Underground coal gasification technology impact on coal reserves in Colombia," Revista Facultad de Ingeniería, 22(35), p. 9. doi: $10.19053 / 01211129.2511$

Self, S. J., Reddy, B. V and Rosen, M. A. (2012) "Review of underground coal gasification technologies and carbon capture," International Journal of Energy and Environmental Engineering, 3(1), p. 16. doi: 10.1186/2251-6832-3-16.

Shackley, S., Reiche, A. and Mander, S. (2004) "The public perceptions of underground coal gasification (UCG): A pilot study," pp. 1-55.

Shafirovich, E. and Varma, A. (2009) "Underground coal gasification: A brief review of current status," Industrial \& Engineering Chemistry Research, 48(17), pp. 7865-7875. doi: 10.1021/ie801569r. 
Shrivastava, R. and Patel, P. (2014) "Hazards identification and risk assessment in thermal power plant," IJERT, 3(4), pp. 463-466. Available at:

https://www.ijert.org/phocadownload/V3। 4/IJERTV3IS040583.pdf.

Sugiyono, A., Anindhita, Wahid, L. M. A. and Adiarso (eds.) (2016) Indonesia Energy Outlook 2016. Jakarta: BPPT-Press. Available at:

https://www.researchgate.net/profile/Agu s_Sugiyono/publication/305875716_Outl ook_Energi_Indonesia_2016/links/5a4f2 c46458515e71b091e67/Outlook-EnergiIndonesia-2016.pdf.

Sury, M., White, M., Kirton, J., Carr, P. and Woodbridge, R. (2004) Review of environmental issues of underground coal gasification - Best practice guide. Report No. COAL R273 DTI/Pub URN 04/1881.

Świądrowski, J. and Stańczyk, K. (2016) "Environmental aspects of underground coal gasification," CHEMIK, 70(5), pp. 243-246. Available at:

http://www.chemikinternational.com/wpcontent/uploads/2016/05/5_16_Swiadro wski_GB.pdf.

The Working Group on UCG (2007) Status report on underground coal gasification. New
Delhi: Principal Scientific Adviser. Available at:

http://psa.gov.in/sites/default/files/book/ Status-Report-on-Underground-CoalGasification/\#p=1.

Torres, V. N., Atkins, A. S. and Singh, R. N. (2014) "Assessment of an environmental sustainability index for the underground coal gasification process by using numerical analysis," in Aziz, N., Kininmonth, B., Nemcik, J., Black, D., Hoelle, J., and Cunbulat, I. (eds.) Proceedings of the 2014 Coal Operators' Conference. University of Wollongong, pp. 309-323. Available at: https://ro.uow.edu.au/coal/526/.

Verma, R. P., Mandal, R., Chaulya, S. K., Singh, P. K., Singh, A. K. and Prasad, G. M. (2014) "Contamination of groundwater due to underground coal gasification," International Journal of Water Resources and Environmental Engineering, 6(12), pp. 303-311. doi: 10.5897/IJWREE2014.0520.

Zulfahmi (2017) Model kekuatan batuan pengapit batubara sebagai respon termal pada proses underground coal gasification (UCG): Studi kasus batuan dari formasi Muara Enim Cekungan Sumatera Selatan. Universitas Padjadjaran. 
